\title{
RESPONSABLES DE LOS ARCHIVOS EN EL SIGLO XVI: CAPITULARES EN EL ARCHIVO DE LA CATEDRAL DE SANTIAGO DE COMPOSTELA
}

\author{
Arturo Iglesias Ortega* \\ Archivo Catedralicio de Santiago
}

\begin{abstract}
Resumen: El Archivo de la Catedral de Santiago adquiere naturaleza a lo largo del siglo XVI en el momento en que ocupa un espacio separado del Tesoro capitular, la gestión y custodia documental queda en manos de miembros del cabildo elegidos periódicamente (procuradores del cabildo, tesoreros de las reliquias, archivistas), apoyados por la labor puntual de otros beneficiados diputados al efecto, y su labor queda reglamentada en las constituciones capitulares pos-tridentinas, singularmente en las de 1578, refrendadas por el arzobispo Francisco Blanco, vigentes durante todo el Antiguo Régimen.

Palabras clave: archivo catedralicio; personal; Santiago de Compostela; siglo XVI.

Title: PROFESSIONALS OF ARCHIVES IN XVITH CENTURY: CHAPTER MEMBERS IN THE CATHEDRAL OF SANTIAGO DE COMPOSTELA'S ARCHIVES.

Abstract: The Archives of the Cathedral of Santiago takes nature throughout the sixteenth century when it occupies a distinct place from chapter's Treasury, records management and custody is in the hands of periodically elected chapter `s members (chapter solicitors, relics treasurers, archivists), supported by the timely work of other chapter members, and their work is regulated in the post-tridentine chapter constitutions, notably in 1578, endorsed by Archbishop Francisco Blanco, in force throughout the Ancient Regime.
\end{abstract}

Keywords: archive staff; cathedral archives; Santiago de Compostela; sixteenth century.

\section{INTRODUCCIÓN}

A lo largo del período medieval, las catedrales y monasterios ocuparon el lugar que dejó el Imperio Romano en materia de archivos, custodiando la documentación de la Iglesia, de otras instituciones públicas y de particulares. En este sentido, el cabildo de la Catedral de Santiago mostró desde muy temprano un notable interés por preservar los documentos y libros de la Iglesia compostelana. Además de su valor litúrgico y cultual (piénsese en el Codex Calixtinus), era primordial su valor probatorio como garante de los derechos jurídicos y patrimoniales de la institución. De ahí que, como en el resto de las catedrales peninsulares, dicha documentación formara parte del Tesoro de la catedral

\footnotetext{
*bulasmix@gmail.com

Recibido: 08/04/2011; 2a revisión: 08/11/2011; aceptado: 14/12/2011.
}

IGLESIAS ORTEGA, A. Responsables de los archivos en el siglo XVI: capitulares en el Archivo de la Catedral de Santiago de Compostela. Anales de Documentación, 2012, vol. 15, $\mathrm{n}^{\circ}$ 1. http://dx.doi.org/10.6018/ analesdoc.15.1.124961. 
junto a ornamentos, reliquias y demás objetos de valor bajo la responsabilidad del tesorero ${ }^{1}$.

Desde que el cabildo se consolida durante el episcopado de Diego Gelmírez (11001140) se registran las primeras iniciativas archivísticas para ordenar y transcribir los documentos antiguos con el ánimo claramente utilitario de facilitar su localización y garantizar su conservación (son los libros tumbo o cartularios), así como para glorificar y afianzar jurídicamente la sede jacobea (por ejemplo, la Historia Compostela o los Gesta Berengarii). En un momento indeterminado de la Baja Edad Media, la documentación de la mitra arzobispal deja de compartir el mismo espacio catedralicio para tener su propio archivo o archivos independientes ${ }^{2}$. Las características de estos archivos eclesiásticos son comunes a todos los archivos de la Iglesia hasta el Concilio de Trento y al resto de los archivos hasta el período bajomedieval: muestran algunos avances en el tratamiento archivístico y se definen por entender la archivística como procedimiento empírico y por constituirse como agentes de la función administrativa ${ }^{3}$.

Con el inicio de la época moderna, la mayor complejidad de los aparatos administrativos de las instituciones, sumado al abaratamiento de la materia escriptoria, propiciaron una verdadera “explosión documental”, lo que motivó que se incrementara su preocupación por la regulación de la gestión de sus archivos con el fin último de reforzar el buen funcionamiento administrativo. En el transcurso del siglo XV al XVI se produce la paulatina segregación del archivo capitular respecto del Tesoro catedralicio: separación física, que se inicia con la construcción de unos armarios de archivo en 1497 y se consuma en el segundo tercio del siglo XVI con la habilitación de un espacio propio en el ala oriental del nuevo claustro renacentista; y autonomía profesional, que se consolida en 1519 con el nombramiento de los predecesores de los archivistas de la catedral, a cuyo cargo estaría la custodia de las escrituras ${ }^{4}$. El tesorero, por su parte, únicamente quedaba a cargo de los libros del coro y del altar que seguían guardándose en el Tesoro a finales de la centuria 5 .

Las transformaciones que en materia de archivística se produjeron en época moderna hay que entenderlas como parte del contexto general de gestación del estado moderno, iniciado durante el gobierno de los Reyes Católicos y consolidado por sus sucesores en lo que se dio en llamar "régimen polisinodial". Los Reyes Católicos desarrollaron el esquema administrativo creado por los Trastámaras en el último tercio del siglo XIV, con la separación de la función gubernamental y judicial a través de los consejos y audiencias, la cual conllevó una dualidad tanto procedimental como documental, que no llegó a consolidarse por la inestabilidad política e incipiente organización gubernativa, caracterizada por una corte itinerante y, en consecuencia, por una ausencia de archivo central $^{6}$. Los grandes hitos archivísticos de este momento, cronológicamente ordenados, serían los siguientes: las ordenanzas de Medina del Campo de 1489 para reorganizar el tribunal y audiencia de Valladolid, disponiendo la creación del Archivo de la Real Chancillería de Valladolid ${ }^{7}$; la instrucción de corregidores dada en Sevilla en 1500, obligando a todos los concejos de las ciudades y villas del reino a tener sus arcas para 
guardar sus privilegios y escrituras, convirtiéndose en la norma más importante aprobada en todo el antiguo régimen sobre archivos municipales ${ }^{8}$; la pragmática de Alcalá del 7 de junio de 1503, regulando el oficio de escribano y dando luz al protocolo notarial tal y como lo conocemos hoy en día ; y el nombramiento hecho por Fernando el Católico en 1509 de una persona para recoger y depositar en un archivo de la Chancillería de Valladolid todos los papeles dispersos relativos a la Corona, antecedente del Archivo de Simancas, creado en 1540 y cuyo reglamento de 1588 está considerado como un hito fundamental en la historia archivística española y europea ${ }^{10}$.

Como ocurrió en la mayoría de los archivos bajo los Austrias, en el archivo catedralicio se conjugaron tres tipos de archivos: un archivo de poder, cuyo objetivo era mantener el control de los individuos e instancias que estaban bajo su autoridad; un archivo de la administración, al servicio de la eficiencia y diligencia administrativas; y un archivo de la historia, centrado en la salvaguarda del pasado y de la memoria ${ }^{11}$.

Quizás el ejemplo más evidente de la concurrencia de estos tres elementos caracterizadores del archivo moderno haya sido, en el caso compostelano, la utilización del famoso diploma apócrifo de Ramiro I (834) para la defensa y cobranza del Voto de Santiago, una renta, pagada normalmente en cereal, que la Iglesia compostelana percibió secularmente de todo agricultor vecino de la mayor parte de la Corona de Castilla y norte de Portugal. El avance territorial de la cobranza del Voto durante las décadas de 14801520 y, sobre todo, de 1560-1580, puso en manos de la Iglesia compostelana (cabildo y mitra, esencialmente) a un enorme contingente poblacional que, en su mayor parte, habitaba en amplias zonas fuera de su control jurídico y fiscal. La conflictividad generada en torno a la percepción de la renta, desarrollada fundamentalmente en el marco de un entramado judicial específicamente creado para dirimir los innumerables pleitos del Voto (las llamadas protectorías o tribunales de los jueces protectores), hizo necesaria la continua disponibilidad de las escrituras del archivo como documentos probatorios en los procesos iniciados, que, en su mayoría, acabaron con sentencias favorables al cabildo ${ }^{12}$. Al tiempo que se perpetuaba su poder recaudatorio, el incremento notable del patrimonio capitular derivó en la necesidad de regular el marco administrativo y burocrático, no sólo el de las administraciones del Voto en Granada y Valladolid, que tuvieron su propio archivo, sino también el de la administración central en Santiago. La estrecha vinculación del archivo con la contaduría de hacienda catedralicia es el testimonio más claro del carácter administrativo del primero. Finalmente, aunque muy ligada al primer aspecto, el valor histórico del archivo compostelano se percibe en la enorme producción historiográfica generada en torno a la legitimidad del Voto, tanto por sus defensores como por sus detractores, cuyo momento de máximo apogeo se produjo en los años 1574$1630^{13}$.

Respecto a los archivos eclesiásticos, hay que esperar al Concilio de Trento para encontrarnos con una política definida de la Iglesia en materia de archivos, concretamente por lo que toca a la generalización y ordenación de los archivos parroquiales y a las consecuencias que sobre la formación de los archivos diocesanos tuvo el decreto que 
obligaba a los obispos a residir y regentar una sola diócesis. La puesta en práctica de los decretos conciliares en España se hace obligada tras la real provisión de Felipe II del 12 de julio de 1563. Pero, aunque no se ocupó de concretar la regulación jurídica de los archivos de la Iglesia (cosa que sí hizo el papa Sixto $\mathrm{V}$ a finales de la centuria, al crear el reglamento y estatuto de los archivos eclesiásticos, que regulaba aspectos como la figura del archivero, los registros documentales y la transferencia de documentos), el espíritu tridentino se manifiesta en la reglamentación archivística de los cabildos catedrales en sus constituciones capitulares ${ }^{14}$. En el caso compostelano, serán las constituciones del arzobispo Gaspar de Zúñiga de 1569 y, sobre todo, del arzobispo Francisco Blanco de 1578 -que estuvieron en vigor hasta las de José María Martín de Herrera de 1899-, las que se ocupen del personal del archivo capitular, que es objeto de este trabajo ${ }^{15}$. Hasta entonces, las actas capitulares constituyen la fuente de información primordial para conocer la evolución y funciones de dicho personal.

Hasta la conformación y extensión de la figura del archivero en la Edad Moderna, hubo muchas otras personas y oficiales que tuvieron alguna participación en las tareas archivísticas $^{16}$. Pero lo que ahora nos ocupa es conocer las características de los oficios servidos por los propios capitulares, relacionados con la custodia y ordenación de la documentación capitular, dejando para otra ocasión todo el cuadro de oficiales, ayudantes, escribientes y demás personal laico asalariado del archivo. Dichos oficios se elegían anualmente en sesión capitular denominada cabildo de oficios, normalmente a principios del mes de agosto, justo al iniciarse el año administrativo, de entre las dignidades, canónigos y racioneros ${ }^{17}$. La duración del mandato era anual, pero eran frecuentes las reelecciones. Además de en esas fechas, podían producirse nuevas elecciones de oficios por diversos motivos: renuncia del elegido antes de jurar el cargo y vacante por defunción, dimisión o ausencia prolongada de su titular ${ }^{18}$. Dicha elección se hacía por mayor número de votos secretos, empleando probablemente cédulas en las que se escribía el nombre del elegido $^{19}$, cuyo escrutinio correspondía a los escrutadores para ello nombrados.

\section{PROCURADORES GENERALES DEL CABILDO}

Los procuradores generales del cabildo eran dos beneficiados (mayoritariamente canónigos, pero también racioneros y, en menor medida, dignidades) elegidos anualmente, cuya labor estaba muy relacionada con la de los abogados del cabildo ${ }^{20}$. Del mismo modo que los letrados laicos se acompañaban de procuradores que ejercían la representación procesal ante los tribunales, estos procuradores ejercen la representación ordinaria de la congregación. Sus funciones, eminentemente jurídicas, han sido esbozadas ya para el siglo XV: aceptación de obligaciones, solicitud de instrumentos públicos, traslados y testimonios notariales, presentación de protestas y apelaciones, prestar juramento en nombre del cabildo, aceptar fianzas de las tenencias, custodia de la documentación capitular,... ${ }^{21}$. Esta última tarea, anteriormente reservada al tesorero, adquiere especial significado, pues, hasta el nombramiento de los primeros archivistas en 1519, serán ellos los encargados de custodiar el arca de las escrituras, cuyas llaves estaban en su poder, 
controlar la incorporación y préstamo de sus documentos, y solicitar copias de los mismos $^{22}$.

Las Constituciones de Gaspar de Zúñiga, seguidas luego por las de Francisco Blanco, inciden en la importancia de recuperar las escrituras de la Iglesia compostelana que se hallaban fuera de sus archivos para presentarlas en pleitos ante las reales audiencias, tribunales eclesiásticos u otros tribunales, y las tocantes a la hacienda capitular que estaban en manos de tenencieros ${ }^{23}$, abogados, arrendadores, escribanos y otras personas desconocidas. Por ello encomiendan a los procuradores del cabildo averiguar dónde están (escribiendo a las personas, procuradores o solicitadores que asisten en los tribunales o a los propios particulares) y recuperar dichas escrituras para ponerlas en el tumbo de las escrituras y entregarlas a los archivistas para que las guarden en el archivo: en caso de originales, solicitándolas al tribunal que las tuviera, una vez se quedasen con un traslado de ellas; en caso de traslados y las que estuvieran en poder de particulares, "se cobren signadas y en forma”. Los procuradores que entonces había, debían dar cuenta de las diligencias realizadas al finalizar el tiempo de su oficio y los que vinieran después, cada seis meses. El no hacerlo suponía el descuento indefinido hasta su cumplimiento ${ }^{24}$, es decir, se les dejaría de contar como presentes a las horas canónicas y demás funciones litúrgicas, de manera que no percibirían la parte de su prebenda correspondiente a las llamadas distribuciones ${ }^{25}$.

El nombre dado a los libros de actas capitulares y tumbos notariales está claramente relacionado con su función de ejecutores de las decisiones tomadas en las sesiones capitulares: los libros do procuratorio ${ }^{26}$. Esta vinculación con las reuniones capitulares va más allá, pues era su cometido traer y repartir entre los canónigos las habas blancas y negras con las que se votaba cada vez que se pidiese alguna gracia en cabildo ${ }^{27}$. Su actividad debía estar controlada, de ahí que el 3 de septiembre de 1507 se acordase que los asuntos encargados a los procuradores de la mesa capitular se asentasen en un memorial firmado por el deán, que se les entregaría cada vez que se celebrase un cabildo.

Según acuerdo capitular del 19 de noviembre de 1488, los procuradores debían hacer y solicitar sin excusa lo allí cometido y dar cuenta de ello, o al menos de las diligencias practicadas al efecto, en el primer cabildo o en el término que el cabildo o el deán previniesen, so pena de descuento ${ }^{28}$. La pena por no ejercer bien su oficio solía ser bastante elevada, dada la gravedad de la falta ${ }^{29}$. Por ello se acordó en sesión del 13 de octubre de 1529 que hiciesen su oficio y acudiesen siempre a cabildo, dejando sustituto cuando tuviesen que ausentarse, pena de 2 reales de plata por cada ausencia suya o de sus sustitutos $^{30}$. Las Constituciones de Francisco Blanco ordenan que asistan siempre a los cabildos, al menos uno de ellos, “y si se hiziere o determinare algo que sea contra constitución, lo contradigan y hagan sobre ello sus diligencias"31.

Junto a estos procuradores generales, se nombraban habitualmente a otros beneficiados como procuradores del cabildo para cuestiones puntuales o de gran importancia, o para 
actuar en tribunales o destinos lejanos, recibiendo por ello un salario a mayores de sus emolumentos como prebendados ${ }^{32}$.

\section{ARCHIVISTAS}

Como ya se ha comentado anteriormente, la custodia de las escrituras y documentos de la catedral estuvo en manos, primeramente, del tesorero $\mathrm{y}$, posteriormente, de los procuradores generales del cabildo, quienes tenían las llaves del arca de las escrituras, que se hallaba en el Tesoro capitular ${ }^{33}$. Aunque los procuradores siguen teniendo el control de las escrituras, en 1518 se registran unos acuerdos capitulares que indican aires de cambio: el 15 de enero se manda "a los que tienen las llaves de las escrituras del cabildo", que llaman tesoreros, den al canónigo D. Pedro de Castilla los privilegios y ejecutorias originales del Voto, tomando conocimiento de ellos; diez días después se les vuelve a mandar que entreguen dichas llaves a dicho canónigo; el 23 de abril mandan al racionero Patiño dar a los "tesoreros del Tesoro", en el plazo de tres días, todas las escrituras pertenecientes a la tenencia grande "para que las tengan en su guarda”, so pena de un mes de descuento ${ }^{34}$. Estos tesoreros se corresponden con toda seguridad a los de las reliquias, quienes tenían las llaves del altar mayor, el cual hacía también las funciones de Tesoro ${ }^{35}$. Está claro que las escrituras continuaron guardándose dentro del Tesoro capitular, a pesar de que ya se comience a utilizar el término "archivo" en estos momentos ${ }^{36}$, probablemente con el significado original de "arca"37.

El 9 de febrero de 1519 nombró el cabildo, por vez primera, a dos prebendados como "llaveros de las escrituras del Tesoro" 38 , y, a partir de 1520, se nombran cada mes de agosto con el título de "guardas del archivo de las escrituras", "guardas de las llaves de las escrituras de la Santa Iglesia”, "guardas de las escrituras” y, ya en la segunda mitad de la centuria, “archivistas” o, más raramente, "archiveros”39.

Con las obras del claustro renacentista se da la ocasión para la construcción de un recinto adecuado para albergar el archivo, encargo que se hace a Rodrigo Gil de Hontañón $^{40}$, y para designar nuevos responsables de la custodia de la documentación: el 17 de noviembre de 1533 se cometió al fabriquero que mandase aderezar los armarios en los que se habían de guardar todos los privilegios, libros y escrituras tocantes al cabildo y al arzobispo, que estaban en el Tesoro, y se pusiesen tres llaves que no se pudiesen abrir sin la presencia de los tres llaveros prebendados que debía nombrar el cabildo para ello ${ }^{41}$. No tenemos constancia de tal nombramiento y siguieron eligiéndose a dos capitulares cada año, que guardarían dichas escrituras y las facilitarían a quien ordenase el cabildo. El control de las escrituras que salen y entran comienza a ser su tarea prioritaria: el 22 de mayo de 1549 se ordena a los "guardas de los archibios adonde están las escripturas” (lo que indica que había más de un lugar de archivo) que no entreguen a ningún beneficiado ni persona alguna ninguno de los tumbos y escrituras de dichos archivos para que los lleven a sus casas ni a otra parte, salvo para que los vean in situ y "saquen dellas lo que fuere menester" ${ }^{\prime 2}$. 
Serán las Constituciones de Gaspar de Zúñiga las primeras en ocuparse de los archivistas -más tarde retomadas literalmente por las de Francisco Blanco ${ }^{43}$-, incidiendo en la necesidad de una mejor custodia de las escrituras de la Iglesia y cabildo, para lo que se les ordena, bajo juramento:

- que no puedan abrir los cajones ni sacar escritura de ellos sin estar presentes ambos y el vicario del deán ${ }^{44}$

- que no permitan sacar ni prestar ninguna escritura original y sólo se saque traslado de ellas por mandato del arzobispo y del cabildo, so pena de excomunión mayor ${ }^{45}$

- que, si se diese alguna escritura por mandamiento judicial, se asiente en el "tumbo y libro de las dichas scripturas” ${ }^{\text {46 }}$ quién la llevó, cómo, cuándo y por mandato de qué juez, firmando el que la llevase con la fecha exacta de salida, y quedando traslado de ella en el archivo. Se debía pedir, además, que, después de haberse presentado el documento ante la justicia, hicieran traslado de ella para devolver el original al archivo

- que, faltando uno de ellos, sólo pueda dejar sus llaves al vicario del deán, y, faltando ambos, las dejen al obrero y vicario conjuntamente ${ }^{47}$

El 17 de noviembre de 1589 se acordó que en lo sucesivo no se diesen libros, conocimientos ni escrituras del archivo sin dejar prenda de oro o plata y conocimiento de quién y cómo se los llevaba ${ }^{48}$.

Como acabamos de exponer, la función de los archivistas se centró en la mera salvaguarda y control de la documentación capitular, encargándose a otros prebendados y ayudantes labores de copia y ordenación ${ }^{49}$. Una vez establecidas las bases estatutarias para mejorar la conservación, las tareas organizativas pasaron a un primer plano, diputándose para ello a prebendados que trabajasen con los archivistas para disponer el traslado de las escrituras a las estancias del nuevo archivo y contaduría ${ }^{50}$.

La Contaduría de Hacienda estuvo estrechamente vinculada al archivo desde su creación en 1529, lo que se evidencia por el hecho frecuente de que alguno de los contadores fuera nombrado al mismo tiempo como uno de los archivistas del año, algo que se explica por la necesaria relación y proximidad física que existía entre la Contaduría y el Archivo, nutriéndose la una de la documentación del otro para realizar sus cuentas y custodiando este los documentos transferidos desde aquella cuando pierden su valor primario $^{51}$. El cargo de archivista, por otra parte, recaía habitualmente en los mismos individuos $^{52}$ y prácticamente siempre repetía alguno de ellos al año siguiente ${ }^{53}$, lo que parece reflejar la conveniencia de mantener un cuadro profesional estable dada la importancia de conocer en todo momento dónde se encontraban los documentos requeridos para poder responder a cualquier negocio o pleito de la Iglesia compostelana.

\section{HISTORIADOR DE LOS MILAGROS}

Sólo hemos hallado tres nombramientos esporádicos en los cabildos de oficios del 1 de agosto de 1496, 1503 y 1504, en que se nombra cronista o “estoriador de los milagros” al 
canónigo Francisco de Vaamonde ${ }^{54}$. No parece casual que el primer año registrado sea el de la peregrinación de los Reyes Católicos a Compostela en agradecimiento al apóstol por la toma de Granada y la finalización del proceso reconquistador, que trajo para Santiago cosas tan importantes como, por ejemplo, el privilegio de los Votos de Granada. Por ese y otros motivos, el papa Alejandro VI les otorga por la bula Si convenit (19 de diciembre de 1496) el título de "católicos”. La relación de los reyes Fernando e Isabel con Compostela viene de más atrás como parte del proceso reformador eclesiástico que querían llevar a cabo y, de manera concreta, del programa de reorganización de la peregrinación jacobea, manifestado en hitos como el hospital real de peregrinos y su cofradía jacobea ${ }^{55}$. Su devoción, especialmente de la reina Isabel, al santo apóstol, “luz y patrón de las Españas” había quedado de manifiesto en múltiples ocasiones ${ }^{56}$. La hipótesis que planteamos es que se quisiese desde el cabildo participar en este nuevo impulso al hecho jacobeo con la designación de un beneficiado que se encargara de registrar cualquier noticia relativa a las nuevas actuaciones milagrosas del apóstol Santiago, tales como su “participación” en la reciente toma de Granada. En cierto modo, estaría inspirado en lo hecho por el papa Calixto II en el libro II del Codex Calixtinus, donde se recopilaban los principales milagros atribuidos al apóstol en toda la Cristiandad con ánimo propagandístico en un momento en el que la peregrinación jacobea necesitaba no acababa de despuntar ${ }^{57}$.

La primera mención de este oficio es del 21 de julio del año 1496, en que el cabildo encarga a los tesoreros del altar, encargados de las limosnas de los peregrinos ${ }^{58}$, que "hagan un libro en que se sienten los miraglos y los fagan sentar en él cada miraglo como acesçiere y ayan informaçión de los que han acaesçido que no son asentados y así mismo los sienten en él so pena de medio año de descuento" 59 . Según López Ferreiro, antes de esta época los prodigios que sucedían en la catedral "se asentaban en papeles sueltos o en el forro de cualquier libro o en otro lugar semejante”, de ahí que se hiciese necesario un libro de registro. Como los tesoreros del altar estaban muy ocupados en aquella época por la afluencia de devotos al santo, se decidió buscar a una persona que escribiese "los milagros de los romeros de Santiago” y para ello se nombró seis días después al bachiller Vaamonde, con salario vitalicio de 1.000 maravedíes $^{60}$. Dicho nombramiento se confirmó en la elección anual de oficios de principios de agosto, como ya se ha dicho. Los otros dos nombramientos registrados, en 1503 y 1504, no debían sino confirmar el nombramiento vitalicio. El canónigo Francisco de Vaamonde era un letrado que había estudiado en el estudio salmantino, fue notario apostólico y actuó como juez en la audiencia arzobispal compostelana y teniente de provisor del arzobispado, es decir, era, además de miembro del cabildo catedralicio, un oficial del arzobispo Alonso de Fonseca II. En 1507 falleció $\sin$ que sepamos que tuviera sucesor en el cargo ${ }^{61}$. Tampoco hay rastro del registro cronístico de los milagros que se le encargó, pero hay testimonios de que la labor se siguió haciendo durante mucho tiempo de manera no sistemática ${ }^{62}$.

\section{CONCLUSIONES}

El Archivo de la Catedral de Santiago adquiere forma definitiva en la primera época moderna, con un espacio propio distinto del Tesoro, donde hasta entonces se guardaban 
las escrituras y libros de la catedral, ubicándose bien entrado el siglo XVI en el nuevo claustro renacentista. Por lo que toca a la gestión y guarda de los fondos documentales, la responsabilidad de las mismas recae siempre en los propios miembros del cabildo y será después del Concilio de Trento cuando se consolide su marco normativo con las constituciones capitulares de 1578, refrendadas por el arzobispo Francisco Blanco, y cuya vigencia se extiende durante todo el Antiguo Régimen.

Si durante casi todo el período medieval era el tesorero, dignidad capitular, el encargado de los objetos y piezas catedralicias más valiosos, entre ellos los documentales y librarios, ya en el siglo XV la tarea de salvaguardar los documentos queda en manos de los procuradores generales del cabildo elegidos entre los propios capitulares, a quienes en 1518 suceden momentáneamente los tesoreros de las reliquias y en 1519 los primeros llaveros o guardas de las escrituras, que en la segunda mitad de siglo, cuando ya hay un Archivo separado del Tesoro, empiezan a ser denominados archivistas, elegidos todos ellos entre las dignidades y canónigos de la catedral. Al margen de la custodia y organización documental, otras tareas como la copia y recogida de escrituras dispersas eran desempeñadas por otros beneficiados de la catedral. En este sentido, es peculiar el oficio de cronista o historiador de los milagros del apóstol Santiago, que aparece coyunturalmente a raíz del impulso que el culto jacobeo recibe de la flamante monarquía hispánica, pero que es reflejo de una actividad jacobea que perdura en el tiempo.

\section{NOTAS}

${ }^{1}$ Véase, por ejemplo, MENDO CARMONA, C. Los archivos y la archivística: evolución histórica y actualidad. En RUIZ RODRÍGUEZ, A. Á. (ed.). Manual de archivística. Madrid: 1994, p. 21-24.

${ }^{2}$ Véase VÁZQUEZ BERTOMEU, M. El archivo de Alonso de Fonseca III, arzobispo de Santiago. Estudios Mindonienses, 2011, $\mathrm{n}^{\circ}$ 17, p. 526-529.

${ }^{3}$ PÉREZ ORTIZ, M.G. y VIVAS MORENO, A. Análisis de la estructura temporal de la archivística eclesiástica. Revista general de información y documentación, 2008, vol. 18, nº 1, p. 218-220.

${ }^{4}$ Véase IGLESIAS ORTEGA, A.; SANDOVAL VEREA, F. y SEIJAS MONTERO, M. Guía del Archivo de la Catedral de Santiago. Santiago: 2007, p. 53-66.

${ }^{5}$ Archivo Catedralicio de Santiago [ACS, a partir de ahora], CF 59, Constituciones de... D. Gaspar de Zúñiga y Avellaneda [CGZ, a partir de ahora], const. 46-49, fol. 14-15v; Constituciones establecidas, por el Illustrissimo, y Reuerendissimo Señor don Francisco Blanco, Arçobispo de Santiago... [CFB, a partir de ahora]. Santiago: 1578 , const. 6 , p. 4.

6 RODRÍGUEZ DE DIEGO, J.L. “Archivos de la Administración Central desde el siglo XV al XX”. Irargi, 1989, II, p. 41-46.

${ }^{7}$ Véase MARTín POSTIGO, M.S. Historia del Archivo de la Real Chancillería de Valladolid. Valladolid: 1979.

8 ZOZAYA MONTES, L. Una revisión de las periodizaciones archivísticas de la Edad Moderna española. Documenta \& Instrumenta, 2008, nº 6, p. 133-144; GARCÍA RUIPÉREZ, M. y FERNÁNDEZ HIDALGO, M. del C. Los archivos municipales en España durante el Antiguo Régimen. Cuenca: 1999, p. 35.

${ }^{9}$ Véase Historia del Derecho Notarial Español, vol. I. Madrid: 1979.

${ }^{10}$ Véase RODRÍGUEZ DE DIEGO, J.L. Instrucción para el gobierno del Archivo de Simancas (1588). Madrid: 1989; ÍDEM. "Significado del proyecto archivístico de Felipe II”. En ALVAR EZQUERRA, A. Imágenes históricas de Felipe II. Madrid: 2000, p. 181-196. 
11 RODRÍGUEZ DE DIEGO, J.L. Archivos del Poder, archivos de la Administración, archivos de la Historia (siglos XVI-XVII). En GENERELO, J.J. y MORENO LÓPEZ, Á. (coords.). Historia de los Archivos y de la Archivística en España. Valladolid: 1998, p. 29-42. Sobre las distintas periodizaciones en la historia de la archivística véase ZOZAYA MONTES, L. Art. cit., p. 119-145.

${ }^{12}$ REY CASTELAO, O. El Voto de Santiago, claves para un conflicto. Santiago: 1993.

13 ÍDEM. La historiografía del Voto de Santiago. Recopilación crítica de una polémica histórica. Santiago: 1985.

14 PÉREZ ORTIZ, M.G. y VIVAS MORENO, A. Art. cit., p. 220-222; RUBIO MERINO, P. Archivística eclesiástica. Nociones básicas. Sevilla: 1999, p. 164-169.

${ }^{15}$ En la práctica, las constituciones de Francisco Blanco se basaron -cuando no copiaron literalmente- en las de su antecesor Gaspar de Zúñiga, quien, siendo visitador de la Universidad de Alcalá, introdujo en 1555 algunas reformas fundamentales en el esquema originario de dicha universidad, entre ellas, las relativas a la designación de responsables concretos de la custodia de su documentación (SOTELO MARTíN, M.E. y PACHECO SAMPEDRO, R. La política archivística de la Universidad de Alcalá durante los siglos XVI al XIX. Una aproximación a su estudio. En CRUZ MUNDET, J.R. (ed.). Archivos universitarios e historia de las universidades, vol. 9. Getafe-Madrid: p. 306-308).

${ }^{16}$ Véase CRUCES BLANCO, E. y ARROYAL ESPIGARES, P. “Los archiveros en la Edad Moderna”. Baetica, 1999, n 21, p. 301-327.

17 En otras catedrales, los cabildos de oficios se hacían en fechas distintas, coincidentes con distintos años administrativos: en Palencia, durante la semana siguiente a la festividad de los Reyes Magos (CABEZA, A. $L a$ vida en una catedral del Antiguo Régimen. [Valladolid]: 1997, p. 53); en Córdoba, a comienzos del mes de julio (VÁZQUEZ LESMES, R. Córdoba y su cabildo catedralicio en la Modernidad. Córdoba: 1987, p. 102-103); en León, a partir del 17 de agosto (VILLACORTA RODRÍGUEZ, T. El cabildo catedral de León. Estudio histórico-jurídico, siglo XII-XIX. León: 1974, p. 282); en Ávila, el 14 de septiembre, festividad de San Cebrián, o el primer día hábil siguiente (LÓPEZ-ARÉVALO, J.R. Un cabildo Catedral de la vieja Castilla. Ávila: su estructura jurídica, s. XIII-XX. Madrid: 1966, p. 245); en Canarias, el 24 de diciembre (QUINTANA ANDRÉS, P.C. A Dios rogando, y con el mazo dando. Fe, poder y jerarquía en la Iglesia canaria. El cabildo Catedral de Canarias entre 1483-1820. Las Palmas de Gran Canaria: 2003, p. 171).

${ }^{18}$ VÁZQUEZ BERTOMEU, M. La institución notarial y el cabildo compostelano (1460-1481). Santiago: 1995, p. 144-146.

${ }^{19}$ Así sucedía, por ejemplo, en el cabildo canario (QUINTANA ANDRÉS, P.C. Op. cit., p. 170). También en Palencia se hacía votación secreta por mayoría (CABEZA, A. Op. cit., p. 53), mientras que en otros cabildos se introducía el sorteo en algunas ocasiones (VÁZQUEZ LESMES, R. Op. cit., p. 103; VILLACORTA RODRÍGUEZ, T. Op. cit., p. 284).

${ }^{20} \mathrm{Al}$ igual que otros oficios, un buen número de los beneficiados repetían en el cargo: de los 96 que lo fueron en el período 1500-1599, 46 (47,92\%) lo fueron en más de una ocasión; 27 (28,12\%) en más de dos; 17 (17,71\%), en más de tres; 8 (8,33\%), en más de cuatro; 4 (4,16\%), en más de cinco; y 2 (2,08\%), en más de seis.

${ }^{21}$ VÁZQUEZ BERTOMEU, M. La institución notarial..., p. 149.

22 Ibid., p. 425-426.

${ }^{23}$ Las tenencias eran un conjunto de bienes capitulares de distinto origen y calidad, que conformaban un lote de propiedades de muy variadas características, administradas a través de subasta pública mediante la cual se fijaba un canon anual a pagar por un tenenciero, que desde 1578 debía ser siempre un beneficiado de la catedral al cual se remataba la tenencia mientras lo fuera (véase IGLESIAS ORTEGA, A.; SANDOVAL VEREA, F. y SEIJAS MONTERO, M. Inventario de “casas y tenencias”. Santiago: 2009, p. 14-18).

${ }^{24}$ ACS, CF 59, CGZ, const. 102, fol. 31v-32v; CFB, const. 36, n 20, p. 59.

25 REY CASTELAO, O. El Voto de Santiago en la España Moderna. Santiago: 1984, t. II, p. 658-660 y $692-$ 696.

${ }^{26}$ VÁZQUEZ BERTOMEU, M. La institución notarial..., p. 534.

${ }^{27}$ ACS, IG 476, Actas, Lib. $n^{\circ}$ 2, fol. 163.

Anales de Documentación, 2012, vol. 15, nº 1 
${ }^{28}$ ACS, IG 478, Actas, Lib. $n^{\circ}$ 4, fol. 82. Las Constituciones de 1578 retoman este acuerdo al establecer que los procuradores "tengan sus memoriales de todos los pleytos que la Iglesia tiene y en el primero cabildo de cada mes den cuenta del estado en que están los dichos pleytos y quales se siguen y quales no, para que el cabildo sepa lo que passa y prouea cerca dello lo que conuenga” ( $C F B$, const. 36, nº 22, p. 60).

${ }^{29}$ Por ejemplo, el 12 de enero de 1504 se mandó al canónigo Fernando de la Torre que usase su oficio de procurador y siguiese y feneciese todas las causas del cabildo que había comenzado ante cualquier justicia donde pendiesen dichos negocios, o, en caso contrario, se le descontase sin remisión "de todas las oras e del pan e de interpresentes e ynteresentes” (ACS, IG 477, Actas, Lib. $n^{\circ}$ 3, fol. 423). El 13 de enero de 1505 mandaron al mismo canónigo y al otro procurador, Gil Pérez, que "den fyn e todos los negoçios e cabsas del cabildo prinçipiadas como por prinçipiar ansí del cabildo como contra él, ansí contra canónigos como contra otras quales quier personas", so pena de un año de descuento (ibid., fol. 427).

${ }^{30}$ ACS, IG 482, Actas, Lib. $n^{\circ}$ 8, fol. 221. Esta pena se aumentó a descuento irremisible el 18 de septiembre de 1536, en que también se acordó que no pudiesen salir del cabildo sin su licencia bajo la misma pena (ACS, IG 484, Actas, Lib. $n^{\circ}$ 10, fol. 417).

${ }^{31} \mathrm{CFB}$, const. 36, n ${ }^{\circ} 22$, p. 60.

${ }^{32}$ Por ejemplo, el 3 de noviembre de 1498 nombraron al canónigo Álvaro Pérez del Villar, estante en curia romana, "procurador en los pleitos e negoçios e cabsas pertenesçientes e tocantes a la mesa capitular (...) contra quales quier persona o personas eclesiásticas e seglares, con poder de jurar e sustitutir”, asentándole un salario anual de 20.000 maravedíes pares de blancas a contar desde el 1 de agosto de ese año (ACS, IG 477, Actas, Lib. $n^{\circ} 3$, fol. 146v).

${ }^{33}$ Este arca debió ser sustituido por unos armarios que se mandaron construir en el Tesoro por acuerdo capitular del 27 de enero de 1497 (ACS, IG 477, Actas, Lib. $n^{\circ}$ 3, fol. 70). El 28 de agosto de 1523 diputaron al cardenal mayor Alonso de Oviedo para que se hiciese "una arca con dos hechadares e dos llaves para en ella se poner los dineros e escripturas del dicho Cavildo" (ACS, IG 480, Actas, Lib. $n^{\circ}$ 6, fol. 375).

${ }^{34}$ ACS, IG 479, Actas, Lib. $n^{\circ} 5$, fol. 222v y 232.

35 Véase ROSENDE VALDÉS, A.A. El siglo XVI: Gótico y Renacimiento en la catedral compostelana. En NÚÑEZ RODRÍGUEZ, M. (ed.). Santiago, la catedral y la memoria del arte, Santiago: 2000, p. 172-175.

${ }^{36}$ Por ejemplo, el 21 de agosto de 1514 mandan poner en el archivo del cabildo la bula que obtuvo el cardenal Puga para que el cabildo pudiese vender y aforar bienes de su mesa (ACS, IG 479, Actas, Lib. $n^{\circ}$ 5, fol. 52v).

${ }^{37}$ Covarrubias define archivo como "los cajones donde están las escrituras públicas y de alguna comunidad" (COVARRUBIAS OROZCO, S. de. Tesoro de la lengua castellana o española. Madrid: 1995, p. 119).

${ }^{38}$ Además, mandaron que "dende aquí adelante se les contase su selario e lo pasado mandaron que se pagase al señor canónigo Vamonde”, procurador del cabildo (ACS, IG 479, Actas, Lib. $n^{\circ}$ 5, fol. 293v). Se produce, de este modo, la transferencia del desempeño desde los procuradores hasta los guardas de las escrituras.

${ }^{39}$ A pesar de que hoy en día el término archivista está en desuso, hemos preferido mantener el nombre que a lo largo del siglo XVI se empleó preferentemente en la catedral compostelana. No fue este un vocablo excepcional, pues desde fines del XVI y, sobre todo, a partir del XVII se extendió portado el ámbito peninsular, especialmente entre las instituciones eclesiásticas (BURÓN CASTRO, T. ¿Archiveros o archivistas? Boletín de la ANABAD, 1994, t. 44, n 3, p. 21-27).

${ }^{40}$ ROSENDE VALDÉS, A.A. Op. cit., p. 150.

${ }^{41}$ ACS, IG 484, Actas, Lib. $n^{\circ} 10$, fol. 35v.

${ }^{42}$ ACS, IG 513, Actas, Lib. $n^{\circ} 13$, fol. 304v.

${ }^{43}$ CFB, const. 36, no 20, p. 59.

${ }^{44}$ O el deán, según las Constituciones de 1578.

${ }^{45}$ Según las Constituciones de 1578, se exceptúa a las escrituras tocantes a la mesa capitular, que podrán darse con licencia del cabildo, dejando constancia de a quién y cómo se dieron.

${ }^{46}$ Las Constituciones de 1569 mandan nombrar a cuatro prebendados para que hiciesen, ante el archivista y el secretario capitular, "requento y memoria e tumbo distinto y claro de cada una scriptura, poniendo el título y cabeça della y la hecha y de quiénes y sobre qué es”, asentando todas las escrituras en un libro o libros encuadernados en pergamino que se debían hacer a tal efecto. Cada cuatro meses debían enseñar al cabildo el trabajo 
realizado, so pena de descuento (ACS, CF 59, CGZ, const. 103, fol. 32v). Las Constituciones de 1578 sustituyen a estos cuatro prebendados por dos beneficiados, que debían ser contados por presentes mientras ocupasen las tardes en hacer tumbo de todas las escrituras "que ay en los archiuos, poniendo en él sobre qué es cada escritura y ante quién passó y en qué caxa y legajo está” ( $C F B$, const. 36, n² 21, p. 59-60).

47 ACS, CF 59, CGZ, const. 101, fol. 31v.

48 ACS, IG 519, Actas, Lib. $n^{\circ}$ 19, fol. 475v. Esto venía sucediendo en la práctica desde mucho antes, como se puede comprobar en algunas actas capitulares (por ejemplo, en ACS, IG 515, Actas, Lib. $n^{\circ}$ 15, fol. 397v, o en ACS, IG 516, Actas, Lib. $n^{\circ}$ 16, fol. 148v).

${ }^{49}$ Por ejemplo, el 31 de enero de 1522 se dio comisión a D. Juan Micael, arcediano de Trastámara, y al canónigo Pedro Gil Falcón para comprar pergamino, papel y tinta con que hacer dos tumbos en los que insertar las tenencias, escrituras y contratos de la Iglesia, así como para pagar a los escribientes necesarios para tal tarea (ACS, IG 480, Actas, Lib. $n^{\circ}$ 6, fol. 217).

${ }^{50}$ Estas se situarían en el segundo cuerpo de la Fachada del Tesoro, obra de Gil de Hontañón, donde actualmente está el vestuario capitular. En ellas se situaría, hacia 1620, la contaduría y, a mediados del siglo XVII, el archivo (ROSENDE VALDES, A.A. Op. cit., p. 151). El 26 de abril de 1596 nombraron al cardenal mayor Antonio Rodríguez y a los canónigos Navarrete, Vivero y Antonio de Cisneros para que, junto a los archivistas Suárez de Tangil y Hevia, “compongan el arquibio nuevo que se a de azer de la manera que mejor fuere necesario para que se tenga luz e claridad de las escrituras y cosas que en él ay”; además, se ordenó a los tenencieros, canónigos y otras personas que tuviesen escrituras, libros y otras averiguaciones de la hacienda del cabildo, que las entregasen a los archivistas en el plazo de 6 días para que, una vez tomasen razón de ellas, se les devolviese, si fuera necesario (ACS, IG 557, Actas, Lib. $n^{\circ}$ 20, fol. 469). El salario recibido variaría en función del trabajo hecho y su calidad, pero el 28 de noviembre de 1597 se estableció en 2 reales por cada día suelto y ferial que se ocupasen en llevarlo a cabo, mañana y tarde (ibid., fol. 650v). El 17 de diciembre de 1599 se cometió al archivista Suárez de Tangil el nombramiento de dos prebendados que le ayudasen al buen concierto del archivo, recibiendo cada uno unos 10 ducados mensuales, dependiendo de lo trabajado (ibid., fol. 912).

${ }^{51}$ He aquí la nómina de los contadores de hacienda del siglo XVI que también fueron archivistas: Lope Raposo (1529), Jorge Vázquez da Costa (1532), Rodrigo Rodríguez (1536-1537, 1543), Lope Raposo (1544-1546), Juan Vidal (1555), Aníbal Rodríguez (1561-1563), Diego Suárez de Tangil (1580-1582, 1585-1592, 1594-1599), Lope Ochoa de Avellaneda (1582, 1584) y Rodrigo de Hevia (1589, 1594-1595, 1597).

52 De los 152 ocasiones en que hemos podido encontrar nombramientos de archivistas entre 1519 y 1599,120 (casi un 79\%) lo fueron, al menos, cuatro veces, como se desprende de la siguiente tabla:

\begin{tabular}{|l|l|l|l|l|l|l|l|l|l|l|}
\hline $\mathbf{N}^{\mathbf{0}}$ veces & $\mathbf{1}$ & $\mathbf{2}$ & $\mathbf{3}$ & $\mathbf{4}$ & $\mathbf{6}$ & $\mathbf{7}$ & $\mathbf{8}$ & $\mathbf{9}$ & $\mathbf{1 0}$ & $\mathbf{2 8}$ \\
\hline Nombramientos & 18 & 8 & 6 & 24 & 12 & 21 & 16 & 9 & 10 & 28 \\
$(\mathbf{\% )}$ & $(11,84)$ & $(5,26)$ & $(3,95)$ & $(15,79)$ & $(7,89)$ & $(13,82)$ & $(10,53)$ & $(5,92)$ & $(6,58)$ & $(18,42)$ \\
\hline
\end{tabular}

Si analizamos la situación por el número de individuos que fueron archivistas (40), un 55\% (22) repitieron más de una vez en el cargo. El caso más espectacular es el del canónigo Diego Suárez de Tangil, que fue archivista en, al menos, 28 ocasiones.

${ }^{53}$ En el período 1519-1599 sólo hemos contabilizado 13 casos en que ninguno de los dos archivistas lo fueron durante el año anterior. Esto se debe en gran medida a que el canónigo Diego Suárez ocupó el cargo de manera prácticamente ininterrumpida desde 1564 hasta 1599.

54 ACS, IG 477, Actas, Lib. $n^{\circ}$ 3, fol. 54, 344 y 414.

55 Véase GARCÍA ORO, J. y PORTELA SILVA, M.J. Las reformas hospitalarias del Renacimiento en la Corona de Castilla. Del Gran Hospital de Santiago a los hospitales generales. Santiago: 2005, p. 19-31; GARCÍA ORO, J. Diego de Muros III y la cultura gallega del siglo XV. Vigo: 1976, p. 33-43.

${ }^{56}$ LÓPEZ FERREIRO, A. Historia de la S. A. M. Iglesia de Santiago de Compostela. Santiago: 1905, t. VII, p. 406-410.

${ }^{57}$ La recopilación textual de los milagros del apóstol Santiago no es exclusiva de la catedral compostelana. Sabemos de un códice del siglo XII de la catedral de Santo Domingo de La Calzada que narra algunos milagros acaecidos a peregrinos compostelanos (RAMÍREZ PASCUAL, T. "Milagros de peregrinos a Santiago. Edición,

Anales de Documentación, 2012, vol. 15, nº 1 
traducción y estudio de la narración de varios 'milagros de peregrinos' conservada en un códice del Archivo de la Catedral de Santo Domingo de La Calzada”. Berceo, 2004, 146, p. 109-136).

${ }^{58}$ El origen de los tesoreros de las reliquias se remonta, como mínimo, a la época del Codex Calixtinus. Entonces existían unos tesoreros del altar mayor, encargados de recoger las limosnas y ofrendas, principalmente en moneda y en cera, que los devotos del Apóstol dejaban en el arca del altar (PÉREZ RODRÍGUEZ, F.J. La Iglesia de Santiago de Compostela en la Edad Media: El Cabildo Catedralicio (1110-1400). Santiago: 1996, p. 122-123, 134 y 152). La elección de estos tesoreros se realizaba a principios de agosto y, a comienzos del siglo XVI se comienza a llamar tesoreros de las reliquias a los tesoreros del altar, lo que indica la importancia de su función de custodia de las mismas. Al menos desde finales del XV están a su cargo las reliquias, que se hallaban en el Tesoro o en otra parte de la iglesia (ACS, IG 477, Actas, Lib. $n^{\circ} 3$, fol. 137). De igual manera, estaban obligados a mostrar dichas reliquias a los peregrinos (ACS, IG 478, Actas, Lib. $n^{\circ}$ 4, fol. 391).

59 ACS, IG 477, Actas, Lib. $n^{\circ}$ 3, fol. 51v.

${ }^{60}$ LÓPEZ FERREIRO, A. Op. cit., p. 378-379.

${ }^{61}$ ACS, IG 476, Actas, Lib. $n^{\circ}$ 2, fol. 109v; ACS, IG 478, Actas, Lib. $n^{\circ}$ 4, fol. 2v; Arquivo Histórico Universitario de Santiago, Protocolos Notariales, Santiago de Compostela, 12, fol. 112-113v.

${ }^{62}$ Véase, por ejemplo, LÓPEZ FERREIRO, A. Op. cit. Santiago: 1907, t. IX, p. 315-324.

\section{BIBLIOGRAFÍA}

BURÓN CASTRO, T. ¿Archiveros o archivistas? Boletín de la ANABAD, 1994, t. 44, nº 3, p. 21-27.

CABEZA, A. La vida en una catedral del Antiguo Régimen. [Valladolid]: Junta de Castilla y León, 1997.

Constituciones establecidas, por el Illustrissimo, y Reuerendissimo Señor don Francisco Blanco, Arçobispo de Santiago, iuntamente con los Illustres Señores Dean y cabildo de la dicha sancta Iglesia, y con su consentimiento, para el buen gouierno de ella, ansi en lo que toca al seruicio del Altar y Coro, y oficios de los Prebendados, y otros ministros, como al cabildo, y conseruacion de la hazienda de la mesa capitular. Santiago de Compostela: s.n., 1578.

COVARRUBIAS OROZCO, S. de. Tesoro de la lengua castellana o española. Madrid: Editorial Castalia, 1995.

CRUCES BLANCO, E. y ARROYAL ESPIGARES, P.J. "Los archiveros en la Edad Moderna”. Baetica, 1999, n 21, p. 301-327.

GARCÍA ORO, J. y PORTELA SILVA, M.J. Las reformas hospitalarias del Renacimiento en la Corona de Castilla. Del Gran Hospital de Santiago a los hospitales generales. Santiago de Compostela: El Eco Franciscano, 2005.

GARCÍA ORO, J. Diego de Muros III y la cultura gallega del siglo XV. Vigo: Galaxia, 1976.

GARCÍA RUIPÉREZ, M. y FERNÁNDEZ HIDALGO, M.C. Los archivos municipales en España durante el Antiguo Régimen. Cuenca: Ediciones de la Universidad de Castilla-La Mancha, 1999.

IGLESIAS ORTEGA, A.; SANDOVAL VEREA, F.M. y SEIJAS MONTERO, M. Inventario de "Casas y tenencias". Santiago de Compostela: Cabildo de la S.A.M.I. Catedral de Santiago, 2009. 
IGLESIAS ORTEGA, A.; SANDOVAL VEREA, F. y SEIJAS MONTERO, M. Guía del Archivo de la Catedral de Santiago. Santiago de Compostela: Cabildo de la S.A.M.I. Catedral de Santiago, 2007.

LÓPEZ FERREIRO, A. Historia de la Santa A. M. Iglesia de Santiago de Compostela. Santiago de Compostela, Imp. y Enc. del Seminario Conciliar Central, 1898-1909, 11 vols.

LÓPEZ-ARÉVALO, J.R. Un cabildo Catedral de la vieja Castilla. Ávila: su estructura jurídica, s. XIII-XX. Madrid: Institución “Alonso Madrigal”, Patronato "José María Cuadrado”, CSIC, 1966.

MARTÍN POSTIGO, M.S. Historia del Archivo de la Real Chancillería de Valladolid. Valladolid: Imp. Sever-Cuesta, 1979.

MENDO CARMONA, C. Los archivos y la archivística: evolución histórica y actualidad. En RUIZ RODRÍGUEZ, A. Á. (ed.). Manual de archivística. Madrid: Editorial Síntesis, 1994, p. 19-38.

PÉREZ ORTIZ, M.G. y VIVAS MORENO, A. Análisis de la estructura temporal de la archivística eclesiástica. Revista general de información y documentación, 2008, vol. 18, no 1, p. 213-237.

PÉREZ RODRÍGUEZ, F.J. La Iglesia de Santiago de Compostela en la Edad Media: El Cabildo Catedralicio (1110-1400). Santiago de Compostela: Xunta de Galicia, 1996.

QUINTANA ANDRÉS, P.C. A Dios rogando, y con el mazo dando. Fe, poder y jerarquía en la Iglesia canaria. El cabildo Catedral de Canarias entre 1483-1820. Las Palmas de Gran Canaria: Cabildo de Gran Canaria, 2003.

RAMÍREZ PASCUAL, T. "Milagros de peregrinos a Santiago. Edición, traducción y estudio de la narración de varios 'milagros de peregrinos' conservada en un códice del Archivo de la Catedral de Santo Domingo de La Calzada”. Berceo, 2004, 146, p. 109136.

REY CASTELAO, O. El Voto de Santiago en la España Moderna. Santiago de Compostela: Universidad de Santiago, 1984, 5 vols. (tesis doctoral parcialmente inédita).

REY CASTELAO, O. El Voto de Santiago, claves para un conflicto. Santiago: Xunta de Galicia, 1993.

REY CASTELAO, O. La historiografía del Voto de Santiago. Recopilación crítica de una polémica histórica. Santiago: Universidad de Santiago, 1985.

RODRÍGUEZ DE DIEGO, J.L. "Archivos de la Administración Central desde el siglo XV al XX”. Irargi, 1989, II, p. 37-101.

RODRÍGUEZ DE DIEGO, J.L. Archivos del Poder, archivos de la Administración, archivos de la Historia (siglos XVI-XVII). En GENERELO, J.J. y MORENO LÓPEZ, A. (coords.). Historia de los Archivos y de la Archivística en España. Valladolid: Universidad de Valladolid, 1998, p. 29-42.

RODRÍGUEZ DE DIEGO, J.L. Instrucción para el gobierno del Archivo de Simancas (1588). Madrid: Ministerio de Cultura, 1989.

RODRÍGUEZ DE DIEGO, J.L. "Significado del proyecto archivístico de Felipe II”. En ALVAR EZQUERRA, A. Imágenes históricas de Felipe II. Madrid: Centro de Estudios Cervantinos, 2000, p. 181-196. 
ROSENDE VALDÉS, A.A. El siglo XVI: Gótico y Renacimiento en la catedral compostelana. En NÚÑEZ RODRÍGUEZ, M. (ed.). Santiago, la catedral y la memoria del arte. Santiago de Compostela: Consorcio de Santiago, 2000, p. 133-183.

RUBIO MERINO, P. Archivística eclesiástica. Nociones básicas. Sevilla: Guadalquivir Ediciones, 1999.

SOTELO MARTÍN, M.E. y PACHECO SAMPEDRO, R. La política archivística de la Universidad de Alcalá durante los siglos XVI al XIX. Una aproximación a su estudio. En CRUZ MUNDET, J.R. (ed.). Archivos universitarios e historia de las universidades, vol. 9. Getafe: Instituto Antonio de Nebrija de Estudios sobre la Universidad, Universidad Carlos III; Madrid: Editorial Dykinson, p. 301-316.

VÁZQUEZ BERTOMEU, M. El archivo de Alonso de Fonseca III, arzobispo de Santiago. Estudios Mindonienses, 2011, n 17, p. 525-573.

VÁZQUEZ BERTOMEU, M. La institución notarial y el cabildo compostelano (14601481). Santiago de Compostela: Universidad de Santiago, 1995 (tesis doctoral parcialmente inédita).

VÁZQUEZ LESMES, R. Córdoba y su cabildo catedralicio en la Modernidad. Córdoba: Publicaciones de la Caja de Ahorros y Monte de Piedad de Córdoba, 1987.

VILLACORTA RODRÍGUEZ, T. El cabildo catedral de León. Estudio históricojurídico, siglo XII-XIX. León: Centro de Estudios e Investigación “San Isidoro”, Caja de Ahorros y Monte de Piedad de León y Archivo Histórico Diocesano, 1974.

VV. AA. Historia del Derecho Notarial Español, vol. I. Madrid: Junta de Decanos de los Colegios Notariales de España, 1979.

ZOZAYA MONTES, L. Una revisión de las periodizaciones archivísticas de la Edad Moderna española. Documenta \& Instrumenta, 2008, nº 6, p. 119-145. 